\title{
Surface roughness of orthodontic band cements with different compositions
}

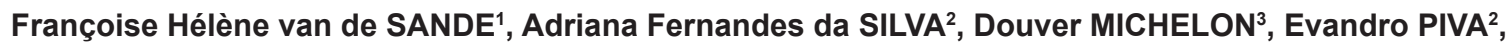 \\ Maximiliano Sérgio $\mathrm{CENCl}^{2}$, Flávio Fernando DEMARCO²
}

1-DDS, Postgraduate student, Dental School, Federal University of Pelotas, Pelotas, RS, Brazil.
2-DDS, MSc, PhD, Professor, Department of Preventive and Social Dentistry, Federal University of Pelotas, Pelotas, RS, Brazil.
3-DDS, PhD, Professor, Department of Operative Dentistry, Federal University of Pelotas, Pelotas, RS, Brazil.

Corresponding address: Dra. Adriana Fernandes da Silva - Faculdade de Odontologia da Universidade Federal de Pelotas - Departamento de Dentística Rua Gonçalves Chaves, 457 - 96015-560 - Pelotas, RS - Brasil - Fax: +55-53-3222-6690 - e-mail: adrisilvapiva@gmail.com

Received: July 20, 2009 - Modification: March 19, 2010 - Accepted: April 29, 2010

\section{ABSTRACT}

\begin{abstract}
O bjectives: The present study evaluated comparatively the surface roughness of four orthodontic band cements after storage in various solutions. Material and Methods: Eight standardized cylinders were made from 4 materials: zinc phosphate cement (ZP), compomer (C), resin-modified glass ionomer cement (RMGIC) and resin cement (RC). Specimens were stored for $24 \mathrm{~h}$ in deionized water and immersed in saline $(\mathrm{pH} 7.0)$ or $0.1 \mathrm{M}$ lactic acid solution ( $\mathrm{pH} \mathrm{4.0)}$ ) for 15 days. Surface roughness readings were taken with a profilometer (Surfcorder SE1200) before and after the storage period. Data were analyzed by two-way ANOVA and Tukey's test (comparison among cements and storage solutions) or paired $t$-test (comparison before and after the storage period) at $5 \%$ significance level. Results: The values for average surface roughness were statistically different $(p<0.001)$ among cements at both baseline and after storage. The roughness values of cements in a decreasing order were $\mathrm{ZP}>\mathrm{RMGIC}>\mathrm{C}>\mathrm{R}(\mathrm{p}<0.001)$. After 15 days, immersion in lactic acid solution resulted in the highest surface roughness for all cements $(p<0.05)$, except for the RC group $(p>0.05)$. Compared to the current threshold $(0.2 \mu \mathrm{m})$ related to biofilm accumulation, both $\mathrm{RC}$ and $\mathrm{C}$ remained below the threshold, even after acidic challenge by immersion in lactic acid solution. Conclusions: Storage time and immersion in lactic acid solution increased the surface roughness of the majority of the tested cements. RC presented the smoothest surface and it was not influenced by storage conditions.
\end{abstract}

Key words: Resin cements. Dental materials.

\section{INTRODUCTION}

Band cementation is customarily performed during orthodontic treatment to improve fixed appliances anchorage and retention in posterior teeth, since the use of brackets may be related to an increased risk of premature debonding at that region ${ }^{2}$. Besides the need for long-lasting retention for fixed appliances, other aspects should be considered to combine strategies aiming at reducing the risk of enamel demineralization, which is frequently related to orthodontic treatment ${ }^{12,14,16}$. Demineralization is the result of biofilm accumulation adjacent to orthodontic bands, and its disorganization is somewhat difficult due to the irregular surfaces around bands. These irregularities create stagnation areas, limiting natural self-cleansing mechanisms and making oral hygiene difficult. Preventive strategies include patient education, fluoride therapies and the selection of orthodontic band cements with satisfactory clinical performance ${ }^{5,7}$.

Materials for orthodontic band cementation should satisfactorily fill the spaces adjacent to the bands, partially preventing biofilm accumulation. Thus, the selection should be carried out considering their ability to seal the interface, the absence of local adverse effects and stability in oral fluids, presenting high tension, shear and compressive strengths ${ }^{25}$. Among the desirable properties, solubility or deterioration of the material bulk, surface roughness and surface free energy are the ones directly involved with biofilm retention. Oral 
fluids and $\mathrm{pH}$ fluctuations on the oral environment play an important role on the degradation of the orthodontic band cements, namely the decrease of surface properties, such as the surface roughness. The exposure to acids could therefore affect the material solubility, thereby changing surface characteristics ${ }^{19}$.

An increase in surface roughness, above the threshold of $0.2 \mu \mathrm{m}$, is considered to predispose to dental biofilm accumulation, resulting in a higher risk for both caries and periodontal inflammation 3,4,20. Additionally, the surface free energy would be associated with biofilm accumulation, and highenergy surfaces would collect more dental biofilm than low-energy surfaces. However, the surface roughness is usually considered the main factor involved in biofilm formation rather than the surface free energy ${ }^{17,20}$.

Many studies have been performed and generated valuable information about the surface behavior of dental materials after acidic exposure ${ }^{13,19,21,26,27}$. Nevertheless, little information is available concerning the surface texture behavior of different orthodontic band cements and how this characteristic would be affected by the exposure to distinct $\mathrm{pH}$ solutions. Therefore, the present study was carried out to evaluate the surface roughness of four materials with different compositions used for band cementation, after storage in solutions with different pHs. The tested null hypothesis was that the cement composition, storage solution and immersion time do not influence the surface roughness.

\section{MATERIAL AND METHODS}

\section{Selection of materials and sample preparation}

Four materials were selected for this study: a zinc phosphate cement (ZP) (DFL, Jacarepaguá, RJ, Brazil), a compomer (Ultra Band-Lok; Reliance Orthodontic Products, Itasca, IL, USA), a resinmodified glass ionomer cement (RMGIC) (RelyX Luting 2; 3M/ESPE, St. Paul, MN, USA) and a resin cement (Enforce; Dentsply, Petrópolis, RJ, Brazil) (Figure 1).

The materials were mixed as recommended by the manufacturer's instructions. A metal matrix (2 $\mathrm{mm}$ thick by $7 \mathrm{~mm}$ diameter) was used to produce standardized cylinders of each cement $(n=8)$. The matrix was placed over a glass plate and then filled with each material; in order to create a flat surface a polyester matrix was adjusted over the surface, and gently pressed with a glass slide. The samples sat

\begin{tabular}{|c|c|c|c|c|}
\hline Material & Classification & Composition (\%) & Manufacturer & $\begin{array}{c}\text { Batch } \\
\text { number }\end{array}$ \\
\hline Zinc phosphate cement & $\begin{array}{c}\text { Conventional } \\
\text { cement }\end{array}$ & $\begin{array}{l}\text { Zinc cement powder (17), Dyes (83). } \\
\text { Phosphoric Acid (0.37), Zinc Oxide (17.73), } \\
\text { Water (81.9). }\end{array}$ & $\begin{array}{c}\text { DFL, } \\
\text { Jacarepaguá, } \\
\text { RJ, BR }\end{array}$ & 405441 \\
\hline Ultra Band-Lok ${ }^{\mathrm{TM}}$ & Compomer & $\begin{array}{c}\text { Glass Frit (4-70), } \\
\text { Amorphous Silica (3-7), } \\
\text { Bisphenol A Diglycidylmethacrylate (8-30), } \\
\text { Sodium Fluoride (1-3). }\end{array}$ & $\begin{array}{l}\text { Reliance } \\
\text { Orthodontic } \\
\text { Products, } \\
\text { Itasca, IL, } \\
\text { USA }\end{array}$ & 208160 \\
\hline RelyX ${ }^{\mathrm{TM}}$ Luting Cement & $\begin{array}{l}\text { Resin-Modified } \\
\text { Glass lonomer }\end{array}$ & $\begin{array}{c}\text { Water }(30-40), \\
\text { Copolymer of acrylic and itaconic acids }(30-40), \\
\text { 2-Hydroxyethyl Methacrylate }(25-35) . \\
\text { Silane treated glass }(<98), \\
\text { Potassium persulfate }(<=0.2)\end{array}$ & $\begin{array}{l}\text { 3M/ESPE, } \\
\text { St. Paul, MN, } \\
\text { USA }\end{array}$ & $\begin{array}{l}\text { EBEC } \\
415 A 3\end{array}$ \\
\hline $\begin{array}{l}\text { EnForce with Fluoride } \\
\text { Multipurpose Adhesive } \\
\text { Cementation System }\end{array}$ & Resin Cement & $\begin{array}{c}\text { TEGDMA, } \\
\text { BDMA, Glass boron silicate } \\
\text { Silanized barium and aluminum, } \\
\text { Camphorquinone, EDAB, BHT, } \\
\text { Mineral pigments, DHEPT. } \\
\text { Carbon Dioxide } \\
\text { Titanium, pyrolytic silica silanized, } \\
\text { Mineral Pigment, Resin Bis-GMA, } \\
\text { BHT, EDAB, TEGDMA, Peroxide } \\
\text { Benzoyl. }\end{array}$ & $\begin{array}{l}\text { Dentsply, } \\
\text { Petrópolis, } \\
\text { RJ, BR }\end{array}$ & $\begin{array}{c}265663 \\
\text { L283637 }\end{array}$ \\
\hline
\end{tabular}

Figure 1- Materials used in this study 
for 10 min before being removed from the matrix. Cement excess was removed with a scalpel. For RMGIC, compomer and resin cement groups the samples were polymerized for $40 \mathrm{~s}$ with a halogen light curing unit (XL 3000; 3M/ESPE) with energy higher than $450 \mathrm{~mW} / \mathrm{cm}^{2}$, which was constantly monitored with a radiometer. For later identification of the reading surface, the one that remained in contact with the glass plate (down side) was marked with a permanent ink pen. The readings were taken on the non-marked surface.

\section{Storing condition}

The cylinders were immediately stored for $24 \mathrm{~h}$ in deionized water at $37^{\circ} \mathrm{C}$ and protected from any source of light irradiation. Four samples of each material were randomly assigned for immersion in saline $(\mathrm{pH} 7.0)$ or $0.1 \mathrm{M}$ lactic acid solution $(\mathrm{pH}$ 4.0), and stored for 15 days. The solutions were renewed every $24 \mathrm{~h}$.

\section{Surface readings}

The surface roughness was determined by a surface profilometer (Surfcoder SE1200; Kosaka Laboratory Ltd., Tokyo, Japan). Readings were performed at baseline (after $24 \mathrm{~h}$ water-storage and before immersion in the test solutions), and after storage in saline or lactic acid solutions (15 days). Average surface roughness ( $\mathrm{Ra} \mu \mathrm{m})$ was obtained by assessing the sample with nine readings, carried out in different angles $\left(0^{\circ}, 120^{\circ}, 240^{\circ}\right)$. The cut-off value was $0.8 \mathrm{~mm}, 0.5 \mathrm{~mm}$ percussion of measure, at $0.5 \mathrm{~mm} / \mathrm{s}$.

\section{Statistical analysis}

Data were transformed ( $\log 10)$ and subjected to two-way ANOVA followed by Tukey's test. Also, paired $t$-test was used for intragroup comparisons at baseline and after the storage time-points. Significance level admitted was 5\%.

\section{RESULTS}

The average surface roughness (Ra) was significantly affected by the type of cement regardless of the time-point evaluated (baseline or after the 15-day immersion period ( $p<0.001$ - Table 1 ; Figure 2). The highest surface roughness was recorded for $\mathrm{ZP}$, followed by RMGIC, compomer and resin cement ( $p<0.05$ - Table 1 ; Figure 2$)$.

Also, immersion for 15 days in both saline and lactic acid solution statistically affected Ra for most of the cements ( $p<0.001$; Table 1$)$. The 15day storage period in saline caused a statistically significant increase in Ra for ZP and $C$, while the same period of lactic acid storage significantly increased Ra for ZP, C and RMGIC samples $(p<0.05$; Table 1$)$. The resin cement samples were

Table 1- Average roughness $(\mu \mathrm{m}) \pm$ standard deviation distribution within groups, at baseline and at the $15^{\text {th }}$ day after immersion in saline or lactic acid solution

\begin{tabular}{lcccc}
\hline Cements & Zinc phosphate & Compomer & $\begin{array}{c}\text { Resin-modified } \\
\text { glass ionomer } \\
\text { cement }\end{array}$ & Resin cement \\
\hline Baseline & $1.02 \pm 0.06$ & $0.11 \pm 0.01$ & $0.28 \pm 0.04$ & $0.08 \pm 0.01$ \\
Saline & $1.27 \pm 0.14$ & $0.13 \pm 0.01$ & $0.30 \pm 0.01$ & $0.09 \pm 0.01$ \\
Lactic acid & $2.28 \pm 0.25$ & $0.16 \pm 0.00$ & $0.34 \pm 0.02$ & $0.09 \pm 0.00$ \\
\hline
\end{tabular}

Considering storage solutions within each cement, groups connected by bars are not statistically different $(p>0.05)$. Within each storage solution/time-point, there were statistically significant differences among cements $(p<0.05)$

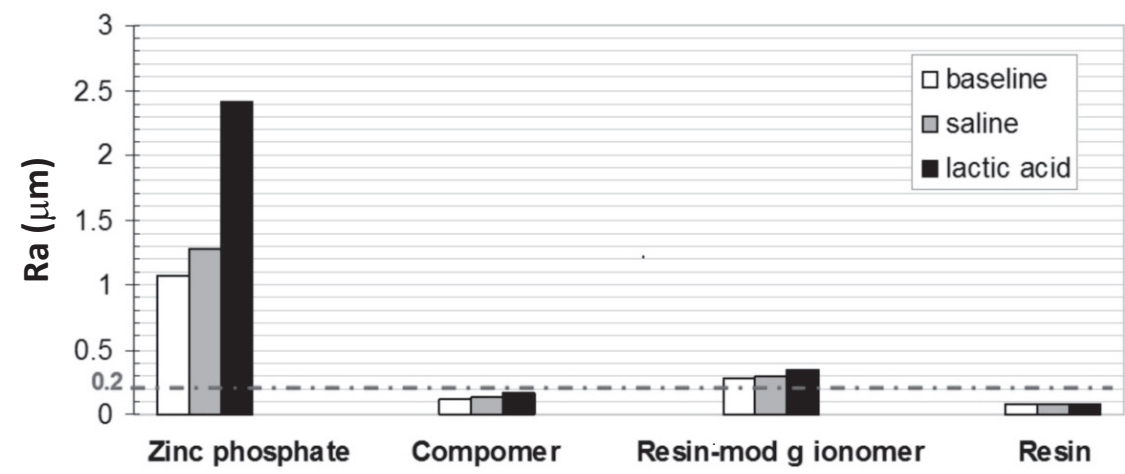

Figure 2- Comparison between the average roughness of cements and the clinical threshold $(0.2 \mu \mathrm{m})$ for surface roughness that would be associated with higher biofilm accumulation 
not affected by storage in either of the solutions ( $p>0.05$; Table 1).

Regarding the critical threshold for biofilm accumulation (Figure 2), ZP group presented Ra values above $0.2 \mu \mathrm{m}$, whereas RMGIC presented values near it, and compomer and resin cement remained under this threshold.

\section{DISCUSSION}

The development of early enamel lesions related to orthodontic treatment with fixed appliance should not be neglected by orthodontists. One strategy to prevent mineral loss would be to minimize the ability for biofilm retention around orthodontic devices ${ }^{6}$. Considering that the surface characteristics influence the rate of biofilm growth, it was valid to verify the behavior of the cements under acidic and aging conditions, observing how they would affect the surface morphology.

In this study, saline was chosen based on its inert characteristic, whereas lactic acid solution was used due to the its obvious role in decreasing the $\mathrm{pH}$ and causing the demineralization process

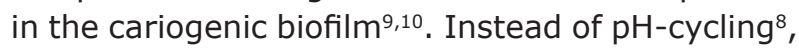
the conditions were performed constantly ${ }^{13}$, so that the surface roughness could be evaluated comparatively for each material in a situation of neutrality or acidity. Moreover, the study design was intended to mimic an extreme cariogenic challenge, in which the material would be exposed to an acidic environment within a confined niche (inside the band) without biofilm removal for long periods.

Considering the obtained results, the null hypothesis was rejected. Another study that investigated the surface texture of GIC-based/ containing restorative materials subjected to different $\mathrm{pH}$ immersion solutions for a week also determined that the surface roughness of all materials was significantly affected by acid solutions, except for the resin composite used as control $^{15}$. Similarly, when investigating the effects of artificial saliva and acid fluoride gel on Ra among GICs, RMGICs and resin composites, Ra greatest changes were observed in the former and minor effects in resin composites ${ }^{28}$. Analyzing other materials, such as adhesives used for bonding orthodontic retainers, aging tests also interfered on surface texture, being able to increase $\mathrm{Ra}$ values $^{18}$. In vitro evaluations, therefore, should always take under consideration at least those minimal challenges, such as acidic exposure and storage period ${ }^{1}$.

In a recent study ${ }^{24}$, it was shown that the initial $\mathrm{pH}$ of the lactic acid solution was affected by the material, especially in the first week of the acidic challenge, probably decurrently of the material degradation. Also, all tested materials (GICs for
Atraumatic Restorative Treatment, a conventional GIC and a resin composite) presented increased $\mathrm{Ra}$ values at the end of the storage period ${ }^{24}$. In the present study the final $\mathrm{pH}$ of the solutions, before each renewal, was not taken and we were not able to evaluate if the ability of the materials to increase the $\mathrm{pH}$ would be related to an increase on surface roughness.

When analyzing studies on cement solubility, one can expect that a higher solubility degree would lead to an increased surface alteration. In a previous study ${ }^{13}$, it was observed that immersion in lactic acid increased the solubility of the tested cements when compared to immersion in saline. Also, the conventional GIC had the highest solubility degree, followed by the RMGIC and compomer, with the lowest solubility degree ${ }^{13}$. The RMGIC and the compomer were the same used in the present study, and the Ra values found were lower for the compomer than for the RMGIC, what could be attributed to the lower solubility of the former.

An in vitro study investigated the ability of luting cements to inhibit artificial caries around filled cavities, and none inhibition zone was observed for zinc phosphate cement, which presented the highest solubility degree. The RMGIC showed less solubility than the zinc phosphate cement, whereas the resin cement presented the lowest solubility 22 . This result for zinc phosphate cement is similar to the findings observed in our study. The resin cement tested in present study, in the evaluated time period, presented surface texture stability even under acidic exposure. The zinc phosphate cement stood far over the threshold $(0.2 \mu \mathrm{m})$ for increased potential of biofilm retention, even at baseline ( $24 \mathrm{~h}$ in deionized water), whereas the compomer and resin groups maintained $\mathrm{Ra}$ values below this threshold (Figure 1).

More complex in vitro studies may answer further questions about the importance and balance of surface characteristics or the capacity to release fluoride over the retention and composition on biofilm development. The role of physical and chemical properties of the surface, and precisely how they affect the competing mechanisms that regulate adhesion of bacteria to surfaces and subsequent biofilm formation remain unclear.

Finally, the balance between demineralization and remineralization determines final outcomes. Biofilm accumulation around orthodontic bands can lead to irreversible lesions with or without cavitation $^{23}$. In an attempt to prevent caries lesions development, the perfect adaptation of the material used, stability in the oral environment and patient education for biofilm removal should all be taken into consideration ${ }^{11}$. 


\section{CONCLUSIONS}

Within the limitations of this in vitro study, it can be concluded that storage time and immersion in lactic acid solution increased the surface roughness of the tested cements. Resin cement presented the lowest roughness and it was not influenced by storage conditions.

\section{ACKNOWLEDGEMENTS}

We would like to thank Ultra Band-Lok ${ }^{\mathrm{TM}}$ (Reliance Orthodontic Products, Itasca, IL, USA), for the donation of the cements used in this study.

\section{REFERENCES}

1- Amaral FL, Colucci V, Palma-Dibb RG, Corona SA. Assessment of in vitro methods used to promote adhesive interface degradation: a critical review. J Esthet Restor Dent. 2007;19:340-53.

2- Banks P, Macfarlane TV. Bonded versus banded first molar attachments: a randomized controlled clinical trial. J Orthod. 2007;34:128-36.

3- Bollen CM, Lambrechts P, Quirynen M. Comparison of surface roughness of oral hard materials to the threshold surface roughness for bacterial plaque retention: a review of the literature. Dent Mater. 1997;13:258-69.

4- Carlén A, Nikdel K, Wennerberg A, Holmberg K, Olsson J. Surface characteristics and in vitro biofilm formation on glass ionomer and composite resin. Biomaterials. 2001;22:481-7.

5- Derks A, Kuijpers-Jagtman AM, Frencken JE, Van't Hof MA, Katsaros C. Caries preventive measures used in orthodontic practices: an evidence-based decision? Am J Orthod Dentofacial Orthop. 2007;132:165-70.

6- Elter C, Heuer W, Demling A, Hannig M, Heidenblut T, Bach FW, et al. Supra- and subgingival biofilm formation on implant abutments with different surface characteristics. Int J Oral Maxillofac Implants. 2008;23:327-34.

7- Featherstone JD. The continuum of dental caries - evidence for a dynamic disease process. J Dent Res. 2004;83(Sp issue):C39-42. 8- Garcez RM, Buzalaf MA, Araújo PA. Fluoride release of six restorative materials in water and $\mathrm{pH}$-cycling solutions. J Appl Oral Sci. 2007;15:406-11.

9- Hojo S, Komatsu M, Okuda R, Takahashi N, Yamada T. Acid profiles and $\mathrm{pH}$ of carious dentin in active and arrested lesions. J Dent Res. 1994;73:1853-7.

10- Hoppenbrouwers PM, Driessens FC. The effect of lactic and acetic acid on the formation of artificial caries lesions. J Dent Res. 1988;67:1466-7.

11- Lima FG, Romano AR, Correa MB, Demarco FF. Influence of microleakage, surface roughness and biofilm control on secondary caries formation around composite resin restorations: an in situ evaluation. J Appl Oral Sci. 2009;17:61-5.
12- Lovrov S, Hertrich K, Hirschfelder U. Enamel demineralization during fixed orthodontic treatment - incidence and correlation to various oral-hygiene parameters. J Orofac Orthop. 2007;68:35363.

13- Lund RG, Silva AF, Demarco FF, Del-Pino FA, Piva E, Michelon $D$. Band cementation materials: solubility and fluoride release. Oral Health Prev Dent. 2008;6:323-9.

14- Mitchell L. Decalcification during orthodontic treatment with fixed appliances-an overview. Br J Orthod. 1992;19:199-205. 15- Mohamed-Tahir MA, Yap AU. Effects of $\mathrm{pH}$ on the surface texture of glass ionomer based/containing restorative materials. Oper Dent. 2004;29:586-91.

16- Ogaard B, Rølla G, Arends J. Orthodontic appliances and enamel demineralization. Part 1. Lesion development. Am J Orthod Dentofacial Orthop. 1988;94:68-73.

17- Quirynen M, Bollen CM. The influence of surface roughness and surface-free energy on supra- and subgingival plaque formation in man. A review of the literature. J Clin Periodontol. 1995;22:1-14. 18- Ramoglu SI, Usumez S, Buyukyilmaz T. Accelerated aging effects on surface hardness and roughness of lingual retainer adhesives. Angle Orthod. 2008;78:140-4.

19- Shabanian M, Richards LC. In vitro wear rates of materials under different loads and varying $\mathrm{pH}$. J Prosthet Dent. 2002;87:650-6.

20- Teughels W, Van Assche N, Sliepen I, Quirynen M. Effect of material characteristics and/or surface topography on biofilm development. Clin Oral Implants Res. 2006;17(Sp issue 2):68-81. 21- Toledano M, Osorio R, Osorio E, Fuentes V, Prati C, GarciaGodoy F. Sorption and solubility of resin-based restorative dental materials. J Dent. 2003;31:43-50.

22- Umino A, Nikaido T, Tsuchiya S, Foxton RM, Tagami J. Confocal laser scanning microscopic observations of secondary caries inhibition around different types of luting cements. Am J Dent. 2005; 18:245-50.

23- Van der Veen MH, Mattousch T, Boersma JG. Longitudinal development of caries lesions after orthodontic treatment evaluated by quantitative light-induced fluorescence. Am J Orthod Dentofacial Orthop. 2007;131:223-8.

24- Wang L, Cefaly DF, Santos JL, Santos JR, Lauris JR, Mondelli $\mathrm{RF}$, et al. In vitro interactions between lactic acid solution and art glass-ionomer cements. J Appl Oral Sci. 2009;17:274-9.

25- Weiner RS. Dental cements: a review and update. Gen Dent. 2007; 55:357-64.

26- Wongkhantee S, Patanapiradej V, Maneenut C, Tantbirojn D. Effect of acidic food and drinks on surface hardness of enamel, dentine, and tooth-coloured filling materials. J Dent. 2006;34:21420.

27- Yanikoğlu N, Yeşil Duymuş Z. Evaluation of the solubility of dental cements in artificial saliva of different $\mathrm{pH}$ values. Dent Mater J. 2007;26:62-7.

28- Yip HK, To WM, Smales RJ. Effects of artificial saliva and APF gel on the surface roughness of newer glass ionomer cements. Oper Dent. 2004;29:661-8. 